Acta Technologica Agriculturae 4

Nitra, Slovaca Universitas Agriculturae Nitriae, 2019, pp. 104-108

\title{
TOTAL SOLID CONTENT AND COMPOUND PROPERTIES FROM DIFFERENT COLLECTION TIME OF HEVEA BRASILIENSIS LATEX
}

\author{
JUNAIDI*, Andi WIJAYA, Arief RACHMAWAN, Mochlisin ANDRIYANTO
}

Sungei Putih Research Centre, Indonesian Rubber Research Institute, Medan, Indonesia

\begin{abstract}
This study compared the total solid content and compound properties of Hevea rubber latex produced from material collected during different periods. Samples were collected from five trees, with the collection replicated three times with tapping task as replication. Observed parameters included total solid content, vulcanization characteristics, technical and physical properties. The results exhibited that the longer latex flowed, the more total solid content tended to decrease. Results indicate that compound of latex collected 20 minutes $\left(C_{20}\right), 60$ minutes $\left(C_{60}\right)$, and 300 minutes $\left(C_{300}\right)$ after tapping qualified for SIR 20 . Other parameters did not show a significant difference among the three tested compounds. Considering the products requiring high dry rubber content, it is suggested not to blend the late collection with main collected latex.
\end{abstract}

Keywords: natural rubber; properties; tapping; vulcanization

Rubber tree (Hevea brasiliensis Muell Arg.) is the most economical species among latex production plants (Priyadarshan, 2011; Venkatachalam et al., 2013). Natural rubber is biosynthesized through the mevalonate (MVA) and 2-C-methyl-D-erythritol 4-phosphate (MEP) pathways in the laticifer tissues (Chow et al., 2012; Ramos et al., 2019). In addition to the rubber particles, latex contains proteins and phospholipids (Ramos et al., 2019). Hevea rubber is mainly cultivated in the tropical region of South and Southeast Asia, South America, and Africa. Indonesia is one of the largest natural rubber producers along with Thailand, India, China, Malaysia, and Vietnam.

Latex is harvested by slicing the bark and subsequent collecting of the dripping latex in a cup. Although Hevea can be tapped anytime, with the recommended time to tap before dawn when there is a high turgor pressure in cells (An et al., 2014). In such manner, latex will immediately flow with maximum velocity after tapping, which will gradually decrease, until it ceases to flow (Yeang, 2005; Bauer et al., 2014). The main latex collection is usually carried out before noon. However, after this main collection, some trees (not all) still release latex at lower flow rate, especially after ethylene stimulation (Shi et al., 2015; An et al., 2016). Some farmers blend this late latex collection with main latex collection, while others leave it in the cup allowing natural coagulation.

Rubber research has been dedicated to optimizing latex yield including rubber breeding and biotechnology (Da Costa et al., 2000; Tang et al., 2016) , tapping method (Lacote et al., 2013; Sainoi et al., 2017), and stimulant application (Zhu and Zhang, 2009; Putranto et al., 2015; Dian et al., 2016). Nonetheless, the effect of environment and agronomical practices on rubber product properties is still not sufficiently comprehended. Moreno et al. (2005) noticed that technical properties varied among rubber clones. Another study by Giraldo-Vásquez and VelásquezRestrepo (2017) showed that seasonal variation influenced rubber technical properties. Janoško et al. (2013) suggested that the composition of rubber compound determined the final product quality.

This study compares the latex total solid content (TSC, \%) and compound properties of latex samples collected at different collection periods. Since particular products require certain minimum values of the observed phenomena, study results could be contributive to latex collection management, as well as rubber processing for obtaining of quality products.

\section{Material and methods}

\section{Sample collection}

An observational study was carried out at Sungei Putih Research Centre, Indonesian Rubber Research Institute, Deli Serdang, Indonesia in September - November 2017 using 12 years old PB 260 rubber clone. Latex was collected from five trees, with the collection replicated three times with tapping task as replication. Tapping activity was executed at 08:00 AM (local time). Latex was collected at 20 minutes after tapping $\left(\mathrm{L}_{20}\right), 60$ minutes after tapping $\left(\mathrm{L}_{60}\right)$, and 300 minutes after tapping $\left(\mathrm{L}_{300}\right)$. The total solid content was measured in accordance with the standard ASTM-D 1076-02 (ASTM International, 2002).

\section{Compound establishment}

Rubber compounds were processed using open mill and formula shown in Table 1. Mastication was performed in five

Contact address: Junaidi, Sungei Putih Research Centre, Indonesian Rubber Research Institute, P.O. Box 1415 Medan 20001, Indonesia, e-mail: junaidi.sp5@gmail.com 
minutes and zinc oxide and stearic acid were added after that. Subsequently, n-cyclohexyl-2-benzothiazole sulphonamide (CBS) and sulphur were mixed into homogenous material, following a 30-minute milling process. Compounds were stored overnight at room temperature prior to the assessment. The $C_{20}$ denotes compound from $L_{20}$, while $C_{60}$ was from $L_{60}$ and $C_{300}$ was from $L_{300}$, respectively.

Table $1 \quad$ The formula for compound establishment
\begin{tabular}{|l|c|}
\hline Material & Amount (phr) \\
\hline Rubber & 100.0 \\
\hline Zinc oxide (ZnO) & 6.0 \\
\hline Stearic acid & 0.5 \\
\hline CBS & 0.5 \\
\hline Sulphur & 3.5 \\
\hline
\end{tabular}

* phr - parts per hundred rubber

\section{Compound assessment}

The compound assessment was carried out at PT. Industri Karet Deli laboratory, Medan. Technical properties observed included Wallace initial plasticity $\left(\mathrm{P}_{0}, \%\right)$, plasticity retention index $(\mathrm{PRI}, \%)$, and Mooney viscosity $\left(\mathrm{V}_{\mathrm{R}}\right)\left(\mathrm{ML}(1+4) 100^{\circ} \mathrm{C}\right)$. Wallace initial plasticity is the average plastimeter reading for the unaged rubber. Plasticity retention index is a measure of the resistance of raw natural rubber to thermal oxidation; a high resistance is shown as a high index value. Mooney viscosity is the viscosity reached after the rotor rotates for a specific duration. Technical properties were assessed according to SNI 1903-2011 (The National Standardization Agency of Indonesia, 2011).

Compound maturation was measured using Moving Die Rheometer 2000 (Alpha Technologies, Washington - USA) at $180^{\circ} \mathrm{C}$ with compound thickness $2 \pm 0.2 \mathrm{~mm}$. Vulcanization characteristics observed included maximum, minimum and delta torque modulus, scorch time, and optimum cure time. Physical properties assessed included hardness, tensile strength, elongation at break, modulus 200, and tear strength. The hardness indicates the compound resistance to permanent indentation. The tensile strength is the maximum stress that the sample can withstand while being stretched or pulled before breaking. The elongation at break is the extent to which a rubber material can be strained before it breaks. The modulus 200 expresses the stress needed to strain the sample for $200 \%$. Tear strength shows the force necessary for ripping the sample and making the crack continue until it fails.

\section{Statistical analysis}

Statistical analysis was performed using R Statistic Software version 3.4.2 (R Development Core Team) in $\mathrm{R}$ Studio Interface version 1.1.383 (R Studio Inc.). Beta regression, a statistical analysis for percentage and proportion data (Mangiafico, 2016), was applied for observation of total solid content, Wallace initial plasticity $\left(P_{0}\right)$, plasticity retention index (PRI), and elongation at break. Mooney viscosity, maximum torque modulus, minimum torque modulus, delta torque modulus, scorch time, optimum cure time, hardness, tensile strength, tear strength, and modulus 200 were analysed with one-way ANOVA. Estimated marginal means were compared on the basis of Tukey comparison method at $\alpha=0.05$.

\section{Results and discussion}

\section{Total solid content}

Total solid content (TSC) indicates the percentage of solid particles contained in the latex. Our results showed that the total solid content tended to decrease with an increase in latex flowing time. The average TSC of $\mathrm{L}_{20}$ was $26.60 \pm 0.25 \%$, while $L_{60}$ and $L_{300}$ were $25.40 \pm 0.14 \%$ and $24.92 \pm 0.08 \%$, respectively. At the beginning of tapping, the latex TSC was high due to a local increment of rubber particles near the tapping cut driven by accelerated rubber biosynthesis (An et al., 2016). Sainoi et al. (2017) suggested that low-frequency tapping did not affect the total solid content, since the gap between two tapping activities was sufficient for rubber regeneration. However, when tapping was combined with ethylene stimulation, a declining trend was noticed (Dian et al., 2016).

Specific products, such as centrifuged latex (Yup and Cacioli, 2002; Maspanger, 2007) and ribbed smoked sheet (RSS), require a certain minimum dry rubber content (DRC, \%) of latex (Morshed et al., 2018). Due to this reason, latex collection management has to take into account the decrease in latex DRC for meeting the factories' processing requirements. Furthermore, anticoagulant needs to be applied wisely, since it affects latex quality as reported by Santipanusopon and Riyajan (2009). For products requiring high DRC, it is recommended not to blend late latex collection with main latex collection. Late latex collection may be stored and processed separately for crumb rubber production, which does not require such high DRC.

\section{Technical properties}

Wallace initial plasticity $\left(\mathrm{P}_{0}\right)$ shows compound's compression ability, while plasticity retention index (PRI) indicates compound oxidation resistance, and Mooney viscosity $\left(V_{R}\right)$ denotes the length of rubber molecules (Zheleva, 2013). The results showed that the latex flowing time significantly affected only the $\mathrm{PRI}$; the $\mathrm{P}_{0}$ and $\mathrm{V}_{\mathrm{R}}$ did not differ significantly in individual treatments. The PRI, along with latex flowing time, indicated an increase; the PRI value of $C_{300}$ was higher than value of $\mathrm{C}_{20}$, yet it was not significantly different from $C_{60}$. The PRI values of $C_{20}, C_{60}$, and $C_{300}$ were $27.00 \pm 1.73 \%$, $27.00 \pm 10.54 \%$, and $41.67 \pm 12.66 \%$, respectively (Table 2). The high PRI value suggested that the compound was resistant to high temperatures. Our results were partially in line with Vachlepi and Purbaya (2018), who reported that low rubber content in latex, similar condition to $C_{300}$, did not affect $\mathrm{P}_{0}$ and $\mathrm{PRI}$ values.

Compound quality including PRI was influenced by the type of anticoagulant (Handayani, 2014) and maturation condition (Intapun et al., 2009). Indonesian National Standard (SNI) set a minimum $\mathrm{P}_{0}$ of $30 \%$ and PRI of $40 \%$ for SIR 20 (SIR - Standard Indonesian Rubber), the common type of crumb rubber produced in Indonesia with regard to the ISO standard, whilst $V_{R}$ value is not specified for SIR 20, but it is required for SIR 20 CV, a variant of SIR 20 (The National 
Table 2 Technical properties of the compounds from different latex collection

\begin{tabular}{|l||c|c|c|}
\hline Compound & $\begin{array}{c}\text { Wallace initial plasticity } \\
\left(\mathbf{P}_{\mathbf{0}}\right)(\mathbf{\%})\end{array}$ & $\begin{array}{c}\text { Plasticity retention index } \\
\text { (PRI) (\%) }\end{array}$ & $\begin{array}{c}\text { Mooney viscosity }\left(\mathbf{V}_{\mathbf{R}}\right) \\
\left(\mathbf{M L} \text { (1+ 4) } \mathbf{1 0 0} \mathbf{0}^{\circ} \mathbf{C}\right)\end{array}$ \\
\hline $\mathbf{C}_{\mathbf{2 0}}$ & $52.33 \pm 12.50 \mathrm{a}$ & $27.00 \pm 1.73 \mathrm{a}$ & $91.70 \pm 1.15 \mathrm{a}$ \\
\hline $\mathbf{C}_{\mathbf{6 0}}$ & $54.00 \pm 7.94 \mathrm{a}$ & $27.00 \pm 10.54 \mathrm{ab}$ & $93.00 \pm 2.95 \mathrm{a}$ \\
\hline $\mathbf{C}_{\mathbf{3 0 0}}$ & $51.33 \pm 6.39 \mathrm{a}$ & $41.67 \pm 12.66 \mathrm{~b}$ & $90.20 \pm 3.80 \mathrm{a}$ \\
\hline & $p=0.9396$ & $p=0.0289$ & $p=0.5232$ \\
\hline
\end{tabular}

Different letters in the same column indicate significant difference based on Tukey's comparison $(\alpha=0.05) ; \pm$ indicate standard deviation $C_{20}$ - Compound from latex collected 20 minutes after tapping; $C_{60}$ - Compound from latex collected 60 minutes after tapping; $C_{300}-$ Compound from latex collected 300 minutes after tapping (late collection)

Table 3 Physical characteristics of the vulcanizes

\begin{tabular}{|c|c|c|c|c|c|}
\hline Compounds & $\begin{array}{c}\text { Maximum torque } \\
\text { modulus } S_{\max }\left(\mathrm{N} \cdot \mathrm{mm}^{-2}\right)\end{array}$ & $\begin{array}{c}\text { Minimum torque } \\
\text { modulus } S_{\min }\left(\mathrm{N} \cdot \mathrm{mm}^{-2}\right)\end{array}$ & $\begin{array}{c}\text { Delta } S_{\max }-S_{\min } \\
\left(\mathrm{N} \cdot \mathrm{mm}^{-2}\right)\end{array}$ & $\begin{array}{c}\text { Scorch time } t_{\mathrm{s} 2} \\
\text { (minutes) }\end{array}$ & $\begin{array}{l}\text { Optimum cure } \\
\text { time } t_{90} \text { (minutes) }\end{array}$ \\
\hline$C_{20}$ & 6.42 & 0.92 & 5.50 & 0.52 & 1.35 \\
\hline$C_{60}$ & 7.09 & 0.82 & 6.27 & 0.48 & 1.37 \\
\hline $\mathrm{C}_{300}$ & 6.39 & 0.74 & 5.65 & 0.51 & 1.40 \\
\hline
\end{tabular}

Table 4 Technical properties of the compounds from different latex collection

\begin{tabular}{|c|c|c|c|c|c|}
\hline Compound & Hardness (Shore A) & $\begin{array}{l}\text { Tensile strength } \\
\left(\mathrm{N} \cdot \mathrm{mm}^{-2}\right)\end{array}$ & $\begin{array}{l}\text { Tear strength } \\
\left(\mathbf{N} \cdot \mathbf{m m}^{-2}\right)\end{array}$ & $\begin{array}{l}\text { Modulus } 200 \\
\left(\mathbf{N} \cdot \mathrm{mm}^{-2}\right)\end{array}$ & $\begin{array}{c}\text { Elongation at break } \\
(\%)\end{array}$ \\
\hline$C_{20}$ & $43.00 \pm 3.00 a$ & $8.49 \pm 7.67 \mathrm{a}$ & $33.34 \pm 2.66 \mathrm{a}$ & $1.35 \pm 0.29 a$ & $495.00 \pm 226.43 a$ \\
\hline$C_{60}$ & $42.00 \pm 2.00 \mathrm{ab}$ & $14.45 \pm 7.88 \mathrm{a}$ & $36.71 \pm 6.68 \mathrm{a}$ & $1.27 \pm 0.15 \mathrm{a}$ & $574.17 \pm 212.23 \mathrm{a}$ \\
\hline \multirow[t]{2}{*}{$C_{300}$} & $35.67 \pm 3.21 \mathrm{~b}$ & $11.95 \pm 4.14 \mathrm{a}$ & $30.07 \pm 3.47 \mathrm{a}$ & $1.04 \pm 0.06 \mathrm{a}$ & $658.33 \pm 73.16 a$ \\
\hline & $p=0.036$ & $p=0.649$ & $p=0.285$ & $p=0.205$ & $p=0.583$ \\
\hline
\end{tabular}

Different letters in the same column indicate significant difference based on Tukey's comparison $(\alpha=0.05) ;+$ indicate standard deviation

Standardization Agency of Indonesia, 2011). Observed results showed that $C_{300}$ qualifies for SIR 20; nonetheless, the $\mathrm{PRI}$ values of $\mathrm{C}_{20}$ and $\mathrm{C}_{60}$ do not qualify for it.

\section{Vulcanization characteristics}

Vulcanization characteristic testing describes the compound vulcanization extent (Cifriadi and Falaah, 2013). Our assessment indicated that three compounds $\left(C_{20}, C_{60}\right.$, and $C_{300}$ ) had relatively similar vulcanization characteristics (Table 3). Torque modulus describes the crosslink density formed during vulcanization, the lower value of $S_{\max }-S_{\min }$ indicates fewer crosslinks between rubber particles with vulcanizing material (Ramadhan and Fathurrohman, 2013). Scorch time $\left(t_{s 2}\right)$ of $C_{20}, C_{60}$, and $C_{300}$ in this study showed a relatively same value, i.e. $0.52,0.48$, and 0.51 minutes, respectively. The optimum cure time ( $t_{90}$, minutes) of $C_{300}$ was slightly higher ( 1.40 minutes) than that of $C_{20}$ ( 1.35 minutes) and $C_{60}$ (1.37 minutes). Vulcanization time is an important parameter related to time and energy efficiency especially in large scale production (Vachlepi and Suwardin, 2015). Research by Utomo et al. (2010) showed that the energy cost of low-grade rubber production was higher than that of the high grade one.

\section{Physical properties}

The hardness determines the appearance and durability of rubber products (Syabani et al., 2018). Result showed that the hardness of $C_{300}$ (35.76 Shore $A$ ) was lower than that of
$C_{20}$ (43.00 Shore A) and $C_{60}$ (42.00 Shore A) (Table 4). However, all samples tested in this study exhibited a normal value for natural rubber around 40 shore $A$. The average tensile strength of $C_{20}$ was $8.49 \mathrm{~N} \cdot \mathrm{mm}^{-2}, C_{60} 14.45 \mathrm{~N} \cdot \mathrm{mm}^{-2}$, and $C_{300}$ $14.45 \mathrm{~N} \cdot \mathrm{mm}^{-2}$, while tear strength of each compound was $33.34 \mathrm{~N} \cdot \mathrm{mm}^{-2}, 36.71 \mathrm{~N} \cdot \mathrm{mm}^{-2}$, and $30.07 \mathrm{~N} \cdot \mathrm{mm}^{-2}$, respectively. Elongation at break values tended to increase with collection time; vice versa, modulus 200 tended to decrease. The average of elongation at break of $\mathrm{C}_{20}, \mathrm{C}_{60}$, and $\mathrm{C}_{300}$ was $495.00 \%, 574.17 \%$, and $658.33 \%$, respectively, while the modulus 200 was $1.35 \%, 1.27 \%$, and $1.04 \%$, respectively.

All physical parameters did not show any significant difference between samples except the hardness. Results indicate that collection time did not affect compounds' physical properties. This study used latex from the same trees and exploited identical preparation procedures; therefore, it is suggested that all samples have a similar rubber structure. Multiple conducted studies (Hidayoko and Wulandra, 2014; Purbaya and Suwardin, 2017) suggest that the coagulating process and reinforcement materials (Al-Nesrawy et al., 2014) play determinative role in final compound properties.

\section{Conclusion}

The total solid content of latex tended to decline along with the collection time period. Therefore, for products requiring high dry rubber content, it is recommended to separate late latex collection from the main latex collection. Latex 
collection period did not affect the technical and physical compound properties. It is suggested that not the collection time, but rather other factors, such as coagulating process and reinforcement material, determine the compound quality.

\section{Acknowledgment}

The authors would like to thank PT. Industri Karet Deli, Medan for laboratory equipment supports and technical assistance during this study.

\section{References}

AL-NESRAWY, S. H. - AL-MAAMORI, M. - HASSANI, A. S. - JAAFAR, H. I. 2014. Effect of mixture of reclaimed tire and carbon black percent on the mechanical properties of SBR/NR blends. In International Journal of Advanced Research, vol. 2, no. 1, pp. 234-243.

AN, F. - CAHILL, D. - ROOKES, J. - LIN, W. - KONG, L. 2014. Real-time measurement of phloem turgor pressure in Hevea brasiliensis with a modified cell pressure probe. In Botanical Studies, vol. 55, no. 1 , pp. 1-11.

AN, F. - ROOKES, J. - XIE, G. - CAHILL, D. - CAI, X. - ZOU, Z. - KONG, L. 2016. Ethephon increases rubber tree latex yield by regulating aquaporins and alleviating the tapping-induced local increase in latex total solid content. In Journal of Plant Growth Regulation, vol. 35, no. 3, pp. 701-709.

ASTM International. 2000. Standard Specification for Rubber Concentrated, Ammonia Preserved, Creamed, and Centrifuged Natural Latex, D1076-02 ed., vol. 09. Pennsylvania: ASTM International.

BAUER, G. - FRIEDRICH, C. - GILLIG, C. - VOLLRATH, F. - SPECK, T. - HOLLAND, C. 2014. Investigating the rheological properties of native plant latex. In Journal of the Royal Society Interface, vol. 11, article no. 20130847.

CHOW, K. S. - MAT-ISA, M. N. - BAHARI, A. - GHAZALI, A. K. - ALIAS, H. - MOHD-ZAINUDDIN, Z. - HOH, C. C. - WAN, K. L. 2012. Metabolic routes affecting rubber biosynthesis in Hevea brasiliensis latex. In Journal of Experimental Botany, vol. 63, no. 5, pp. 1863-1871.

CIFRIADI, A. - FALAAH, A. F. 2013. Kinetics study of sulfur vulcanization on unfilled natural rubber compound. In Jurnal Penelitian Karet, vol. 31, no. 2, pp. 159-167. (In Indonesian: Studi kinetika vulkanisasi belerang pada kompon karet alam tanpa bahan pengisi).

DA COSTA, R. B. - DE RESENDE, M. D. V. - DE ARAUJO, A. J. GONÇALVES, P. DE S. - SILVA, M. DE A. 2000. Maximization of genetic gain in rubber tree (Hevea) breeding with effective size restriction. In Genetics and Molecular Biology, vol. 23, no. 2, pp. 457-462.

DIAN, K. - OKOMA, M. K. - GNAGNE, M. Y. - GABLA, R. O. OBOUAYEBA, S. 2016. Impact of intensive stimulation with Ethephon in downward tapping on the potential of production in upward tapping in GT 1 clone of Hevea brasiliensis. In International Journal of Current Science, vol. 19, no. 3, pp. E 11-23.

GIRALDO-VÁSQUEZ, D. H. - VELÁSQUEZ-RESTREPO, S. M. 2017. Variation of technological properties of field natural rubber lattices from Hevea brasiliensis clones and natural rubber-based compounds. In Revista DYNA, vol. 84, no. 203, pp. 80-87.

HANDAYANI, H. 2014. Effect of various type of solid coagulants on the quality of coagulum and vulcanized natural rubber. In Jurnal Penelitian Karet, vol. 32, no. 1, pp. 74-80. (In Indonesian: Pengaruh berbagai jenis penggumpal padat terhadap mutu koagulum dan vulkanisat karet alam).

HIDAYOKO, G. - WULANDRA, O. 2014. Effect of the latex coagulant used to quality of SIR 20. In Agritepa, vol. 1, no. 1, pp. 119-130.
(In Indonesian: Pengaruh penggunaan jenis bahan penggumpal lateks terhadap mutu SIR 20).

INTAPUN, J. - SAINTE-BEUVE, J. - BONFILS, F. - TANRATTANAKUL, V. - DUBREUCQ, E. - VAYSSE, L. 2009. Characterisation of natural rubber cup coagula maturation conditions and consequences on dry rubber properties. In Journal of Rubber Research, vol. 12, no. 4, pp. 171-184.

JANOŠKO, I. - POLONEC, T. - CHRASTINA, J. 2013. Comparison of summer and winter tyres on a dry and snowy surface. In Acta Technologica Agriculturae, vol. 16, no. 1, pp. 5-9.

LACOTE, R. - DOUMBIA, A. - OBOUAYEBA, S. - GOHET, E. 2013. Tapping panel diagnosis, decision support tool for more sustainable rubber tapping system. In IRRDB-MRPPA International Workshop on the Development of Smallholder Rubber Industry in Myanmar. https://doi.org/10.13140/RG.2.1.3148.7527.

MANGIAFICO, S. S. 2016. R Handbook: Beta Regression for Percent and Proportion Data. Retrieved June 26, 2019 from http:// rcompanion.org/handbook/J_02.html

MASPANGER, D. R. 2007. Preparation of creamed latex by low speed centrifugation process and the quality of its rubber product. In Agritech, vol. 27, no. 3, pp. 124-129. (In Indonesian: Pembuatan lateks dadih dengan proses sentrifugasi putaran rendah dan kualitas barang jadi karetnya).

MORENO, R. M. B. - MARISELMA, F. - GONÇALVES, P. D. S. MATTOSO, L. H. C. 2005. Technical properties of latex and natural rubber of Hevea brasiliensis clones. In Scientia Agricola, vol. 62, no. 2, pp. 122-126.

MORSHED, A. J. M. - HELALI, O. H. M. - MOSTAFA, M. - BAKAR, M. A. - DAS, S. K. 2018. A review-production of ribbed smoked sheet in Chattogram Hill Tracts of Bangladesh and assessment of heavy metals in itself. In Journal of Applied Chemistry, vol. 11, no. 1, pp. $10-14$.

PRIYADARSHAN, P. M. 2011. Biology of Hevea Rubber. Oxfordshire: CAB International, 234 pp. ISBN 9781845936662.

PURBAYA, M. - SUWARDIN, D. 2017. Qualitative analysis of coagulant type in the raw rubber material. In Jurnal Penelitian Karet, vol. 35, no. 1, pp. 103-114. (In Indonesian: Pengujian kualitatif terhadap jenis koagulan dalam bahan olah karet).

PUTRANTO, R. - HERLINAWATI, E. - RIO, M. - LECLERCQ, J. PIYATRAKUL, P. - GOHET, E. - SANIER, C. - OKTAVIA, F. - PIRRELLO, J. - KUSWANHADI-MONTORO, P. 2015. Involvement of ethylene in the latex metabolism and tapping panel dryness of Hevea brasiliensis. In International Journal of Molecular Sciences, vol. 16, pp. 17885-17908.

RAMADHAN, A. - FATHURROHMAN, M. I. 2013. The effect of stearic acid on curing characteristic, mechanical properties and swelling oforganoclay filled natural rubber vulcanizates. In Jurnal Sains Materi Indonesia, vol. 14, no. 2, pp. 108-113. (In Indonesian: Pengaruh asam stearat terhadap karakteristik pematangan, sifat mekanik dan swelling vulkanisat karet alam dengan bahan pengisi organoclay).

RAMOS, M. V. - DEMARCO, D. - DA COSTA SOUZA, I. C. - DE FREITAS C. D. T. 2019. Laticifers, latex, and their role in plant defense. In Trends in Plant Science, vol. 24, no. 6, pp. 553-567.

SAINOI, T. - SDOODEE, S. - LACOTE, R. - GOHET, E. 2017. Low frequency tapping systems applied to young-tapped trees of Hevea brasiliensis (Willd. ex A. Juss.) Müll. Arg. in Southern Thailand. In Agriculture and Natural Resources, vol. 51, no. 4, pp. 268-272.

SANTIPANUSOPON, S. - RIYAJAN, S. A. 2009. Effect of field natural rubber latex with different ammonia contents and storage period on physical properties of latex concentrate, stability of skim latex and dipped film. In Physics Procedia, vol. 2, pp. 127-134.

SHI, M. J. - CAI, F. G. - TIAN, W. M. 2015. Ethrel-stimulated prolongation of latex flow in the rubber tree (Hevea brasiliensis 
Muell. Arg.): an Hev b 7-like protein acts as a universal antagonist of rubber particle aggregating factors from lutoids and C-serum. In Journal of Biochemistry, vo. 159, no. 2, pp. 209-216.

SYABANI, M. W. - FAUZIYYAH, F. I. - MUTIARA, T. 2018. Effect of the addition of rubber reclim from side product of outsole on fisis and thermal properties boot outsole product (study case at CV. Carita Niaga)). In Jurnal Sains Dan Teknologi Lingkungan, vol. 10, no. 1, pp. 26-40. (In Indonesian: Pengaruh penambahan karet reklim dari limbah outsole terhadap sifat fisis dan sifat thermal produk outsole sepatu (studi kasus di CV. Carita Niaga).

TANG, C. - YANG, M. - FANG, Y. - LUO, Y. - GAO, S. - XIAO, X. - AN, Z. - ZHOU, B. - ZHANG, B. - TAN, X. - YEANG, H. - QIN, Y. - YANG, J. - LIN, Q. - MEI, H. - MONTORO, P. - LONG, X. - QI, J. - HUA, Y. HE, Z. - SUN, M. - LI, W. - ZENG, X. - CHENG, H. - LIU, Y. - YANG, J. - TIAN, W. - ZHUANG, N. - ZENG, R. - LI, D. - HE, P. - LI, Z. - ZOU, Z. - LI, S. - LI, C. - WANG, J. - WEI, D. - LAI, C. - LUO, W. - YU, J. - HU S. - HUANG, H. 2016. The rubber tree genome reveals new insights into rubber production and species adaptation. In Nature Plants, vol. 2, pp. 1-10.

The National Standardization Agency of Indonesia. 2011. SNI 1903-2011: Rubber Technical Specification. Jakarta: The National Standardization Agency of Indonesia. 13 pp.

UTOMO, T. P. - HASANUDIN, U. - SUROSO, E. 2010. Comparative study of low and high-grade crumb rubber processing energy. In Proceeding of The World Congress on Engineering 2010. London, vol. 3, pp. 2449-2453. ISBN 9789881821089.

VACHLEPI, A. - PURBAYA, M. 2018. Effect of latex dilution on chatacteristics and technical qualities of natural rubber. In Prosiding Seminar Nasional Hasil Litbangyasa Industri 2018, pp. 106-117. AGUSTINI, S. - SUSANTO, T. (Eds.). Palembang: Balai Riset dan Standardisasi Industri Palembang. (In Indonesian: Pengaruh pengenceran lateks terhadap karakteristik dan mutu teknis karet alam)

VACHLEPI, A. - SUWARDIN, D. 2015. Study of the natural rubber compound making from coal briquette ash and palm shell charcoal fillers. In Jurnal Dinamika Penelitian Industri, vol. 26, no. 1, pp. 1-19. (In Indonesian: Kajian pembuatan kompon karet alam dari bahan pengisi abu briket batubara dan arang cangkang sawit).

VENKATACHALAM， P. - GEETHA， N. - SANGEETHA， P. THULASEEDHARAN, A. 2013. Natural rubber producing plants: an overview. In African Journal of Biotechnology, vol. 12, no. 12, pp. 1297-1310.

YEANG, H. 2005. The kinetics of latex flow from the rubber tree in relation to latex vessel plugging and turgor pressure. In Journal of Rubber Research, vol. 8, no. 3, pp. 160-181.

YUP, E. - CACIOLI. 2002. The manufacture of gloves from natura rubber latex. In Journal of Allergy and Clinical Immunology, vol. 110 , no. 2, pp. S3-S14.

ZHELEVA, D. 2013. An attempt for correlation between Mooney viscosity and rheological properties of filled rubber compounds. In Journal of Chemical Technology and Metallurgy, vol. 48, no. 3 , pp. 241-246.

ZHU, J. - ZHANG, Z. 2009. Ethylene stimulation of latex production in Hevea brasiliensis. In Plant Signaling and Behavior, vol. 4, no. 11, pp. 1072-1074. 